\title{
Research of parameters of the steam boiler BKZ-220-100 at joint burning of natural gas and low-grade fuel
}

\author{
Elena Vorontsova ${ }^{1}$, Andrey Gil ${ }^{1, *}$, and Alexander Romanenko ${ }^{1}$ \\ ${ }^{1}$ National Research Tomsk Polytechnic University, 634050 Tomsk, Russia
}

\begin{abstract}
In this article the research of prospects of use of low-grade brown coal of the Talovsky Deposit of the Tomsk region as fuel for local power is carried out. The study is carried out by checking calculations of the steam boiler BKZ-220-100. The result of the study is to obtain data on the parameters of the boiler during the combustion of brown talovsky coal as the main fuel, as well as in a mixture with natural gas or Kuznetsk coal.
\end{abstract}

\section{Introduction}

Brown coal of the talovsky Deposit of the Tomsk region has the following characterized by high humidity in a wide range $(20 \%-60 \%)$, low heat of combustion, large yield of volatile. Such parameters of brown coal indicate that this fuel is low-grade and its use is economically feasible only for the needs of local energy [1].

The object of the study is a steam boiler with natural circulation BKZ-220-100. The boiler unit is operated at Tomsk SDPP-2.

The aim of the work is to study the parameters of the steam boiler in the combined combustion of brown talovsky coal and natural gas.

\section{Initial data and research methods}

Due to the wide range of moisture content of brown coal of the talovsky Deposit, using the methods of numerical simulation of combustion processes, the optimal for combustion in the boiler furnace BKZ-220-100 values of fuel moisture. Fig. 1 shows the temperature change in the height of the combustion chamber of the boiler under study when burning tall brown coal with a moisture content of $20-50 \%$ and Kuznetsk coal.

\footnotetext{
*Corresponding author: angil@tpu.ru
} 


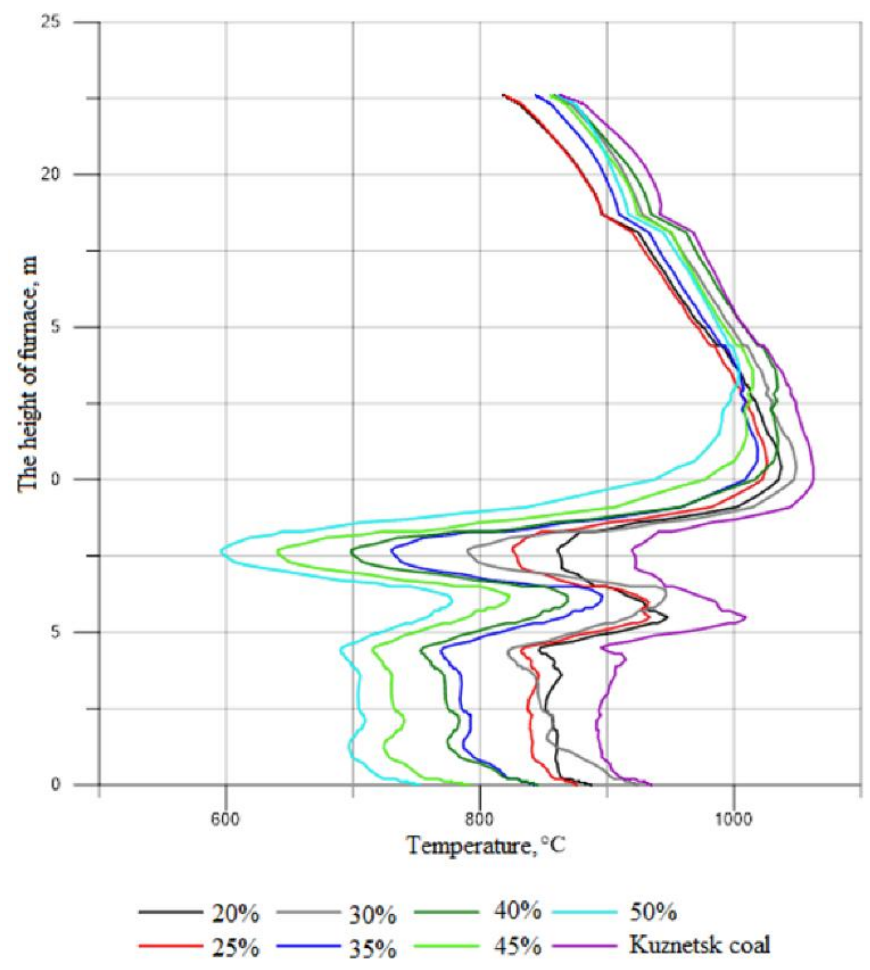

Fig. 1. The temperature Distribution along the height of the boiler furnace.

Fig. 1 shows that the temperature distribution in the boiler furnace height depends on the humidity of the talovsky coal, i.e. as the humidity of the burned talovsky coal increases, the temperature in the area of the burner devices decreases. In addition, there is a similar pattern of temperature distribution in the combustion of talovsky coal with a moisture content in the range of $25-30 \%$ and Kuznetsk coal [2].

As a result of numerical simulation of the combustion process of tall brown coal in the furnace of the steam boiler BKZ-220-100, the optimal range of fuel moisture was determined, which was $25 \%-30 \%$. The conclusion of numerical modeling is the conclusion that the mathematical model of the boiler furnace

BKZ-220-100 is suitable for further research. The obtained concentration fields of particles, water vapor and temperature regime in the combustion volume correspond to the accepted combustion scheme [2]. For further research, the selected coal with a moisture content of $25 \%$.

The initial characteristics of the talovsky brown coal with a moisture content of $25 \%$ are presented in table 1 .

Table 1. Features Talovsky brown coal with a moisture content of $25 \%$ in working condition.

\begin{tabular}{|c|c|c|c|c|c|c|c|c|}
\hline \multirow{2}{*}{$\begin{array}{c}\text { Moisture } \\
\text { content } W^{r} \text {, } \\
\%\end{array}$} & \multirow{2}{*}{$\begin{array}{c}\text { Ash content } \\
A^{r}, \%\end{array}$} & \multirow{2}{*}{$\begin{array}{c}\text { Volatile } \\
\text { yield } \\
V^{\text {daf }}, \%\end{array}$} & \multirow{2}{*}{$\begin{array}{c}\text { Low heat of } \\
\text { combustion } \\
Q_{i}^{r}, \mathrm{MJ} / \mathrm{kg}\end{array}$} & \multicolumn{5}{|c|}{ Ultimate analysis (dry ash-free basis, \%) } \\
\hline & & & & $C^{r}$ & $H^{r}$ & $N^{r}$ & $S^{r}$ & $O^{r}$ \\
\hline 25.00 & 27.69 & 63.1 & 14.05 & 30.55 & 3.19 & 12.93 & 0.09 & 0.55 \\
\hline
\end{tabular}

After determining the optimal humidity, the calibration calculation of the boiler BKZ220-100 was performed for the burning of brown coal from the Talovsky Deposit, as well 
as mixtures of brown coal with natural gas and brown coal with Kuznetsk coal, which is designed for the boiler unit under study.

Calculations for the combustion of a mixture of coal is made as an alternative, as natural gas is more expensive fuel compared to Kuznetsk coal and its combustion is less costeffective. coal.

Table 2 presents the characteristics of natural gas, table 3 - characteristics of Kuznetsk

Table 2. Characteristics of natural gas.

\begin{tabular}{|c|c|c|c|c|c|c|}
\hline $\begin{array}{c}\text { Methane } \\
\mathrm{CH}_{4} \\
\%\end{array}$ & $\begin{array}{c}\text { Dioxide } \\
\mathrm{CO}_{2} \\
\%\end{array}$ & $\begin{array}{c}\text { Ethane } \\
\mathrm{C}_{2} \mathrm{H}_{6} \\
\%\end{array}$ & $\begin{array}{c}\text { Propane } \\
\mathrm{C}_{3} \mathrm{H}_{8} \\
\%\end{array}$ & $\begin{array}{c}\text { Bhutan } \\
\mathrm{C}_{4} \mathrm{H}_{10} \\
\%\end{array}$ & $\begin{array}{c}\text { Nitrogen } \\
\text { N } \\
\%\end{array}$ & $\begin{array}{c}\text { Low heat } \\
\text { of } \\
\text { combustion, } \\
Q_{d}^{r} \\
\mathrm{MJ}^{3}\end{array}$ \\
\hline 98.72 & 0.14 & 0.12 & 0.01 & 0.01 & 1.00 & 34.86 \\
\hline
\end{tabular}

Table 3. Characteristics of Kuznetsk coal.

\begin{tabular}{|c|c|c|c|c|c|c|c|c|}
\hline \multirow{2}{*}{$\begin{array}{c}\text { Moisture } \\
\text { content } W^{r} \text {, } \\
\%\end{array}$} & \multirow{2}{*}{$\begin{array}{c}\text { Ash content } \\
A^{r}, \%\end{array}$} & \multirow{2}{*}{$\begin{array}{l}\text { Volatile } \\
\text { yield } \\
V^{\text {daf }}, \%\end{array}$} & \multirow{2}{*}{$\begin{array}{c}\text { Low heat of } \\
\text { combustion } \\
Q_{i}^{r}, \mathrm{MJ} / \mathrm{kg}\end{array}$} & \multicolumn{5}{|c|}{ Ultimate analysis (dry ash-free basis, \% } \\
\hline & & & & $C^{r}$ & $H^{r}$ & $N^{r}$ & $S^{r}$ & $O^{r}$ \\
\hline 13.8 & 14.4 & 24.0 & 20.92 & 55.7 & 4.0 & 9.9 & 0.3 & 1.9 \\
\hline
\end{tabular}

\section{Results}

The parameters of the boiler operation at the brown angle with a moisture content of $25 \%$ are presented in table 4 .

Table 4. Parameters of the boiler BKZ-220-100 in the combustion of brown coal.

\begin{tabular}{|c|c|c|}
\hline Name & Dimension & Value \\
\hline Low heat of fuel combustion & $\mathrm{MJ} / \mathrm{kg}$ & 14.052 \\
\hline $\begin{array}{c}\text { Excess air ratio at the exit of the } \\
\text { furnace }\end{array}$ & - & 1.2 \\
\hline Boiler efficiency & $\%$ & 92.237 \\
\hline Exit-gas temperature & ${ }^{\circ} \mathrm{C}$ & 136 \\
\hline Fuel consumption & $\mathrm{kg} / \mathrm{c}$ & 10.97 \\
\hline $\begin{array}{c}\text { Flue gas temperature at the exit of } \\
\text { the furnace }\end{array}$ & ${ }^{\circ} \mathrm{C}$ & 900 \\
\hline Temperature of superheated steam & ${ }^{\circ} \mathrm{C}$ & 454 \\
\hline
\end{tabular}

Check calculation of the boiler during combustion in its combustion chamber of talovsky coal with a moisture content of $25 \%$ showed that without the reconstruction of the heating surfaces the required temperature of superheated steam is not achieved.

The results of verification calculations for the combustion of talovsky coal with natural gas and Kuznetsk coal are presented in tables $5-6$. 
Table 5. Parameters of the boiler BKZ-220-100 when burning a mixture of tall brown coal and natural gas.

\begin{tabular}{|c|c|c|c|c|c|}
\hline \multirow{2}{*}{ Name } & \multirow{2}{*}{ Dimension } & \multicolumn{4}{|c|}{ Brown coals content, \% } \\
\cline { 3 - 6 } & & 30 & 40 & 50 & 60 \\
\hline Low heat of fuel mixture combustion & $\mathrm{MJ} / \mathrm{kg}$ & 46.84 & 35.13 & 28.10 & 23.42 \\
\hline Boiler efficiency & $\%$ & 93.11 & 93.22 & 93.32 & 93.19 \\
\hline Exit-gas temperature & ${ }^{\circ} \mathrm{C}$ & 135 & 134 & 133 & 135 \\
\hline Coal consumption & $\mathrm{kg} / \mathrm{c}$ & 3.39 & 4.50 & 5.60 & 6.68 \\
\hline Gas consumption per 1 kg of coal & $\mathrm{m}^{3} / \mathrm{kg}$ & 0.94 & 0.61 & 0.40 & 0.27 \\
\hline Gas consumption & $\mathrm{m}^{3} / \mathrm{c}$ & 3.19 & 2.72 & 2.26 & 1.80 \\
\hline $\begin{array}{c}\text { Flue gas temperature at the exit of the } \\
\text { furnace }\end{array}$ & ${ }^{\circ} \mathrm{C}$ & 1132 & 1081 & 1043 & 1006 \\
\hline The temperature of cold air & ${ }^{\circ} \mathrm{C}$ & 52 & 51 & 50 & 55 \\
\hline The temperature of hot air & ${ }^{\circ} \mathrm{C}$ & 348 & 338 & 337 & 320 \\
\hline The temperature of hot water & ${ }^{\circ} \mathrm{C}$ & 303 & 298 & 296 & 284 \\
\hline Temperature of superheated steam & ${ }^{\circ} \mathrm{C}$ & 510 & 510 & 510 & 497 \\
\hline
\end{tabular}

The test calculations of the boiler under study when using a mixture of talovsky brown coal and natural gas as a fuel showed that the required parameters of superheated steam are achieved at a fraction of brown coal in the range from $30 \%$ to $50 \%$.

With a decrease in the proportion of brown coal below 30\%. there is a danger of exceeding the temperature of the flue gases at the exit of the furnace over the temperature of the beginning of deformation of the ash of the brown coal. which is equal to $1180^{\circ} \mathrm{C}$. The maximum share of brown coal in the fuel mixture at which the required temperature of superheated steam is reached is $50 \%$.

The increase in the share of talovsky brown coal leads to a decrease in temperature parameters. however. the boiler efficiency increases. This is due to the decrease in the volume of flue gases and their temperature.

Table 6. Parameters of the boiler BKZ-220-100 when burning a mixture of tall brown coal and Kuznetsk.

\begin{tabular}{|c|c|c|c|c|c|}
\hline \multirow{2}{*}{ Name } & \multirow{2}{*}{ Dimension } & \multicolumn{4}{|c|}{ Brown coals content. \% } \\
\cline { 3 - 6 } & & 10 & 20 & 30 & 40 \\
\hline Low heat of combustion of fuel mixture & $\mathrm{MJ} / \mathrm{kg}$ & 20.23 & 19.55 & 18.86 & 18.17 \\
\hline Boiler efficiency & $\%$ & 92.2 & 92.25 & 92.36 & 92.57 \\
\hline Exit-gas temperature & ${ }^{\circ} \mathrm{C}$ & 134 & 135 & 135 & 136 \\
\hline The flow rate of the mixture & $\mathrm{kg} / \mathrm{c}$ & 7.94 & 8.18 & 8.45 & 8.72 \\
\hline $\begin{array}{c}\text { Flue gas temperature at the exit of the } \\
\text { furnace }\end{array}$ & ${ }^{\circ} \mathrm{C}$ & \multirow{2}{*}{1098} & \multirow{2}{*}{1080} & \multirow{2}{*}{1061} & \multirow{2}{*}{1038} \\
\hline The temperature of cold air & ${ }^{\circ} \mathrm{C}$ & 47 & 50 & 50 & 54 \\
\hline The temperature of hot air & ${ }^{\circ} \mathrm{C}$ & 352 & 349 & 347 & 335 \\
\hline The temperature of hot water & ${ }^{\circ} \mathrm{C}$ & 304 & 301 & 297 & 292 \\
\hline Temperature of superheated steam & ${ }^{\circ} \mathrm{C}$ & 510 & 510 & 510 & 503 \\
\hline
\end{tabular}

Results of verification calculations of the steam boiler BKZ-220-100 at burning of a mixture of brown coal with project Kuznetsk coal (table 6) allow to draw a conclusion that the maximum share of brown coal with a moisture content of $25 \%$ in the mixture is $30 \%$. With the increase of the share of talovsky brown coal. the temperature parameters are reduced. due to the decrease in the heat of combustion of the mixture. Boiler efficiency increases by reducing the volume of flue gases and their temperature. 


\section{Conclusion}

The study showed that the use of brown coal from the talovsky Deposit of the Tomsk region with a moisture content of $25 \%$ as a fuel for local energy is possible. However use it for combustion in the boiler BKZ-220-100 working as a part of the power unit of Tomsk SDPP-2. it is advisable only in a mixture with natural gas or Kuznetsk coal.

\section{References}

1. E. V. Chernyaev, V. K. Bernatonis, G. Yu. Boyarko, Materials of the International conference "100 years in the service of science and production". Regional geology. Geology of mineral deposits (TPU publ., Tomsk, 2001)

2. T. S. Taylasheva, A. V. Gil, E. S. Vorontsova, Proceedings of Tomsk Polytechnic University. Georesources engineering 327 (1), 128 (2016) 